補緅誌, J Jpn Prosthodont Soc, 34 : 372 384, 1990.

\title{
原著論文
}

\section{成人正常者および歯周病罹患者における下顎の側方運動 に伴う顆頭の挙動について}

\author{
近江谷尚紀 \\ Comparative Studies of Condylar Movements on Adult Men and \\ Periodontal Patients During Quantitative Lateral Movement
}

\author{
Naoki Omiya
}

\begin{abstract}
We constructed a small number superposition graph by computer program on a cephalometric laminagraph of five adult men and five periodontal patients who have all their teeth of maxillo-mandibular. Research was done on the sideway movements of the non-working side of the condyle which are fixed to be $1 \mathrm{~mm}, 2 \mathrm{~mm}$ and $3 \mathrm{~mm}$ quantitative lateral movement in anterior.
\end{abstract}

These results are as follows:

1. The research of the movement of the condyle was on the basis of condylar top and condylar center. The condylar movement with right and left side quantitative lateral movement of the adult men indicated a distinct straight line type. But, the periodontal patients indicated a distinct zigzag line type. However, the moving condition of two measuring points on both subjects were much alike.

2. In spite of the condition of the occlusal surface of periodontal patients are different from that of adult men, it could be proved that the moving type of the condylar with the lateral movement is a bodily shift.

3. For both much and little quantity of lateral movement, the degree of moving obliquely of periodontal patients' condylar was less than that of the adult men's condylar.

4. Doubted that the difference of occlusal condition between periodontal patients and adult men were chosen on this study.

Key words : periodontal patients, lateral movement, condylar movement, zigzag line, bodily shift

奥羽大学歯学部歯科補棳学第 2 講座 (指導 : 田島篤治教授) Ohu University School of Dentistry Department of Re- movable Prosthodontics (Director : Prof. Tokuji Tajima) 平成元年 10 月 16 日受付 


\section{I. 緒 論}

下顎の側方運動は咀嚼運動の主要な運動として, また, 咬合面の作業咬合小面の形態構成要素として, 歯科補緅 学分野にあっては特に重要視され，今日までに多数の研 究者によって調查と検討が行われてきだ ${ }^{128}$. この結果, 下䫑運動における前方要素としての切歯点部については 十分な資料が提供されていると考える。

一方，顆頭 (下顎頭) の動きに関しては，下顎骨自体 の生物的特殊性および外部計測によらなければならない 計測上の方法論から，その举動の詳細に関しては必要か つ十分な結果が報告9 17) されているとはいえない状 況 にある. 特に, 加龄，咬耗などの条件変化に伴う顆頭の 挙動に関しては，ほとんど報告されたことはなかった. そこで著者は，このような分野に関する調查の第一歩と して，下䫟の定量側方運動に伴う関節䆟内における顆頭 の挙動に関して, 頭部規格断層 X 線撮影装置 Sectograph による規格断層X線写真の computer による複数 画像重ね合せ技法 superposition method ${ }^{18)}$ によって, 上下顎全歯を有する成人正常者および歯周病羅患者につ いて，下顎の側方運動に伴う非作業側の顆頭の挙動に関 する診査を行い，両者間の比較，検討を行った.

\section{II. 研究方法}

\section{1. 被験者および被験顎の状態}

成人正常者としては 18〜26 歳までの女性 2 名, 男性 3 名であり, 一方, 歯周病䍜患者としては 29〜41 歳まで の女性 2 名，男性 3 名である．いずれの被験者にあって も，咬頭嵌合位において早期接触が認められず，第 3 大 白歯以外の歯の欠如はなく，また，歯冠補緅物は咬頭内 斜面部にとどまるむのであり，さらに，咀嚼筋群および 顠関節の異常が認められないものを選択した.

また, 歯周病罹患者の選択にあたっては, 次項に記す ような諸調査を行ったが，最も重要視した条件は第 3 大 臼歯以外の歯の欠如が認められないことである.才なわ ち，歯列中間の歯の欠損がある場合には，歯軸に近遠心 的な側方荷重が生した場合，歯列群としての相互負担形 式に大きな相違が生じるので，歯槽骨の吸収状態に関す る条件が著しく異なり同一被験者群としての条件設定が できない.このような立場から，非常に多数の歯周病䍜 患者の中から本研究の目的にそった 5 名を厳選した.

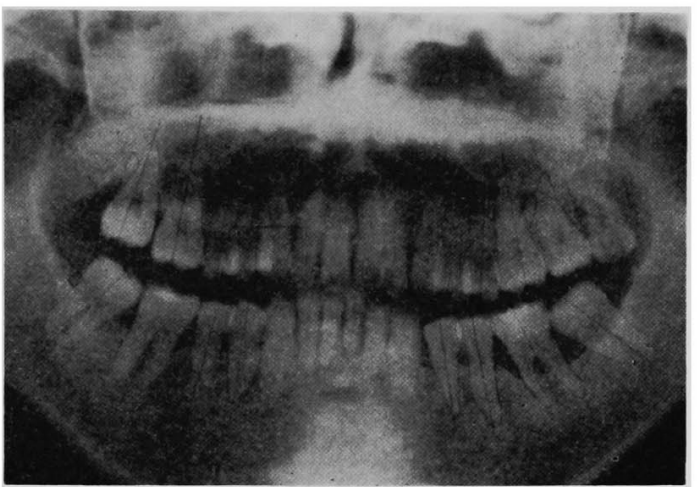

図 1 歯周病䍜患者のパントモグラム

2. 被験者の歯周病罹患状態に関する基礎診查

歯周病䍜患状態に関する診查は, (1) 歯周ポケットの深 さ (2) 歯の動摇度 (3) 茵肉の炎症状態 (4) 歯槽骨吸収状態 である. なお, 歯槽骨吸収状態を除く 3 項目の診查結果 については，いずれも多数の対象者の中から歯周ポケッ トの深さ，歯の動摇度拉よび歯肉の炎症状態に関する臨 床的観察において全く異常を認めない成人正常者 $\mathrm{a} \sim \mathrm{e}$ を選択した。

1）歯周ポケットの深さ

煩側ならびに舌側における近心，中央および遠心の 6 点法 ${ }^{19)}$ のなかで最も大きな值を歯周ポケットの深さ (mm)とした.

2) 歯の動摇度

一般的な方法 ${ }^{19)}$ により動摇度を調ぺ, $\mathrm{M}_{0}, \mathrm{M}_{1}, \mathrm{M}_{2}$ お よび $\mathrm{M}_{3}$ と表示した.

3）歯肉の炎症状態

Löe and Silness $の$ Gingival index ${ }^{20)}$ で診査し, 評価 ナる部位を煩側中央部とした.

4）歯槽骨吸収状態

各歯の歯槽骨の吸収状態診査は Pantomogram で計測 を行った（図 1).この方法は，X線写真の拉大図上で 各歯それぞれについて 8 点ないし 10 点の標点を選択し， digitizer 上において基準点を input し computer によ り自動的に歯冠歯根比を算出した（図 2 ). 計測の実際 にあたっては，まず歯軸の方向の規定を行った．歯冠部 近遠心最長距離部 2 点, 歯根部における近遠心的彎曲を 示さない部位（歯根先端 $1 / 4$ 位）における 2 点を記憶さ せた，複根歯にあっては全歯根幅径を基準とし，上顎大 臼歯にあっては舌側根を対象として選び，さらに歯の全 長は咬合面部 1 点あるいは近遠心最高位 2 点, 歯根先端 部 1 点あるいは 2 点を選び全長を算出した。，一方，歯槽 骨縁の位置については，歯槽骨が鋭角的状態を示さずに 

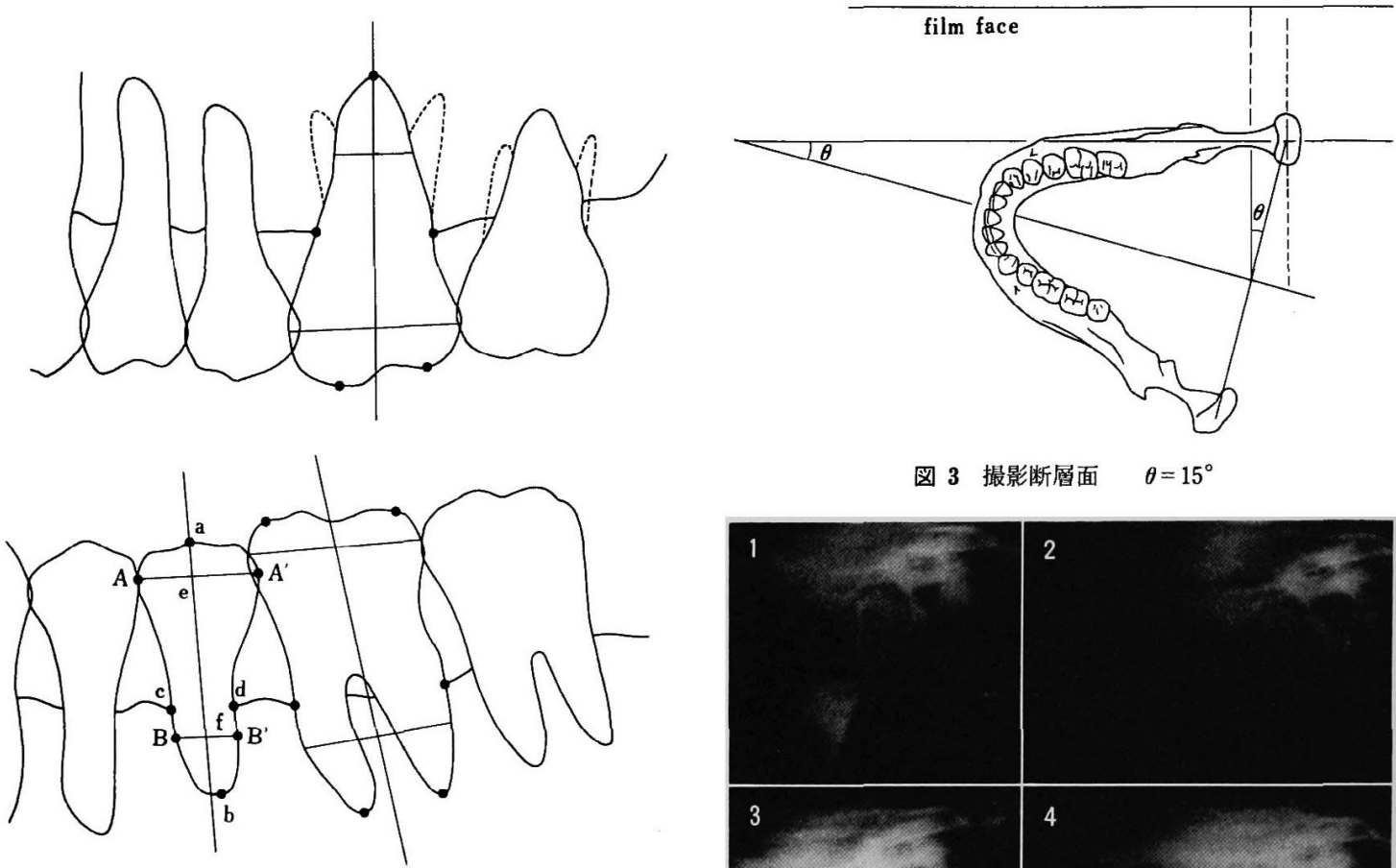

图 3 撮影断層面 $\theta=15^{\circ}$

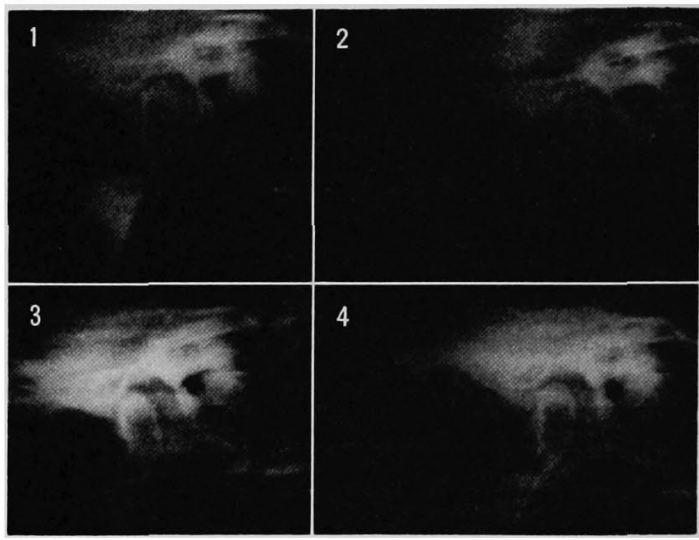

図 2 歯冠歯根比を求めるための計測点

$\mathrm{A}-\mathrm{A}^{\prime}$ : 歯冠部の近遠心最長距離部

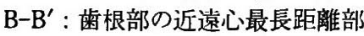

e : 歯冠部近遠心最長距離部の中点

f : 歯根部近遠心最長距離部の中点 $e \sim f:$ 㐘軸

歯面から離開している例にあっては，歯槽骨が根面から $1.0 \mathrm{~mm}$ の距離に接近した位置をもって㐘槽骨縁とみな し，近遠心部それぞれにおける骨縁部 2 点を input し た.

\section{3. 下顎側方運動に伴う顆頭の挙動診查方法}

1）頭部規格断層X線撮影装置 (Sectograph) および 撮影方法

頭部規格断層 X線撮影装置として, 米国 Quint Sectograph を使用した. Sectograph は, cephalograph（X線 規格撮影) と laminagraph (断層撮影) との機構を合わ せ持つX線撮影装置である. 本 Sectograph は断層面の 規格化が容易であり，比較的明膫な規格写真が得られ る21．また, 頭部規格断層 X線撮影にあたっては, 顆頭 長軸と周囲組織の左右側的位置関係から算出される解剖 学的平均値を参考とすると同時に，颚関節撮影の基準で ありかつ補緅学上重要な非作業側の顆頭の運動方向に近 似で，顆頭中央を通りフィルム方向へ $15^{\circ}$ 回転させた矢

図 4 セクトグラムの一例

$1:$ 咬頭嵌合位

$2: 1 \mathrm{~mm}$ 側方運動時

$3: 2 \mathrm{~mm}$ 側方運動時

$4: 3 \mathrm{~mm}$ 側方運動時

状断面を対象として撮影を行った ${ }^{21)}$ (図 3 ).

撮影断層面の決定にあたっては，すでに発表した Sectograph による撮影に関する基礎的検討結果より，正中 から顆頭の煩舌側的中央までの垂直距離を規定した ${ }^{21)}$. なお，撮影側がフィルム面に対面するように，被験者に 撮影用椅子に通常の座位の姿勢をとらせた．また，頭部 の固定にあたっては両側外耳道に ear rod を挿入し，前 後的あおりの固定にあっては眼窩下部に接触する補助固 定装置を用いた。これにより左右 ear rod 基部上縁，お よび眼窩下点を含む平面を水平に定位させることが可能 である.

撮影条件は，X線管球の焦点を $1.0 \times 1.0 \mathrm{~mm}^{2}$, 焦点 フィルム間距離を $1,670 \mathrm{~mm}$, フィルム一断層面間距離 を平均 $96 \mathrm{~mm}$, 管電圧を $76 \mathrm{kV}_{\mathrm{p}}$, 管電流を $100 \mathrm{~mA}$, 照

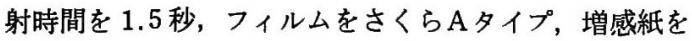


東芝 EM とした。なお，有効管球移動角度は $15^{\circ}$ であ る. 撮影後のフィルム処理にあたっては,さくら VX 400 自動X線フィルム現像機を使用して 90 秒間ですべての 処理を行った (図 4).

2）精度検定および拡大率

（1）精度検定

Sectograph の撮影断層範囲は頭部正中よりフィルム 側方向へ 0〜100 mm，管球側方向へ0〜70 $\mathrm{mm}$ である. 影関節の撮影にあたっては，左右いずれの場合にあって もフィルム側方向である ${ }^{21)}$ ，なお，被験者の両顆頭中央 間距離は $108.4 \pm 5.7 \mathrm{~mm}$ である。 また，断層撮影時に おける円の歪率は $\pm 0.3 \%$ である ${ }^{21)}$.

(2) 拡大率

本研究の应大率は $1.061 \pm 0.002$ であり, 補正は行わ ず，データの処理はすべてX線フィルム上のものとして 行った ${ }^{211}$.

\section{3）撮影額位}

撮影額位は，咬頭嵌合位および定量側方運動時非作業 側である．側方運動量の規定にあたっては，上䫓両中切 歯中央を基準として下影切歯にノギスにて $1 \mathrm{~mm}$ 間隔で 歯面にマーキングを行った．被験者に対しては運動方向 の規定を行うことなく数回の練習後, $\mathrm{COE}$ 社製常温重合 レジンにて上下䅡両犬歯間で固定し，撮影時における位 置ずれに備えた，なお，このレジンプレート中央を開空 し移動量の確認を行った．したがって，両側 4 側ずっ合 計 8 側についての撮影を行った. なお，ここでいう側方 運動とはいわゆる「側方滑走運動」と同意であるが，撮 影にあたっては静止状態での撮影となるのであえて滑走 運動という表現を避けた。

\section{4. 顆頭の挙動分析方法}

1) Computer operated superposition method によ る分析

各撮影颔位に扔ける規格断首 X線写真 sectogram に ついて, Nikon 社製 Profile projecter V-12 を用いて 10 倍大のトレーシングを行い計測原図とした，咬頭嵌合位 における T.M.J. の形態を degitizer 上においてトレー シングを行い, 日本電気社製 PC9801F3 により記録さ せ, computer によって顆頭の移動後の位置，方向およ び距離を算出すると同時に computer graph を自動作図 させた.

なお，咬頭嵌合位を基準とし，顆頭頂 (condylar top) および F-H 平面に垂直で，顆頭頂下 $5 \mathrm{~mm}$ の点を computer operated superposition method ${ }^{18)}$ の基準点とし,

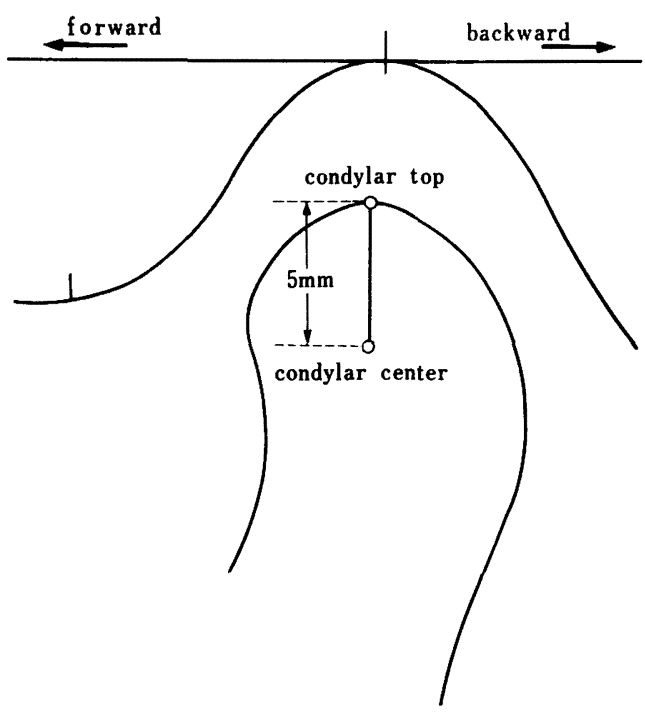

図 5 顆頭の計測点

顆頭頂 : F-H 平面の平行移動時における顆頭の接点 顆頭中心点: $\mathrm{F}-\mathrm{H}$ 平面に垂直で顆頭頂下 $5 \mathrm{~mm}$ の点

両者を結んだ直線を移動の基準線とした．また下方の点 を顆頭中心点 (condylar center) とした (図 5 ).

2）下頡の定量側方運動に伴う顆頭の挙動分析

成人正常者 5 名および歯周病䍜患者 5 名について, 前 述の撮影顎位から得られた顆頭移動図 small number superposition $\mathrm{graph}^{18)}$ を基礎資料として，つぎのよう な各診查を行った.

（1）咬頭嵌合位を基準とした場合における顆頭頂およ び顆頭中心点の移動

(2) 顆頭頂と顆頭中心点との移動傾向の比較

（3）成人正常者および歯周病櫂患者との顆頭移動傾向 の比較

\section{III. 研究結果}

1. 被験者の蒌周病䍜患状態に関する基礎診査結果

1）歯周ポケットの梁さ（表 1 )

被験者 $\mathrm{f}$ における上下顎, 左右側の全臼歯群の歯周ポ ケットの梁さの平均值は $4.3 \mathrm{~mm}$ であり, $\mathrm{g}$ においては $6.1 \mathrm{~mm}, \mathrm{~h}$ においては $3.0 \mathrm{~mm}, \mathrm{i}$ においては $2.9 \mathrm{~mm}$ お

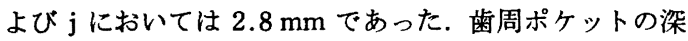
さからは, 被験者 $\mathrm{g}$ が最も不良な臨床所見を呈し，つい で $\mathrm{f}, \mathrm{h}, \mathrm{i}$ および $\mathrm{j}$ の順であった. さらに，全臼歯の菌 周病䍜患者 5 名すべてにおける深さの平均値は $3.9 \mathrm{~mm}$, SD は $1.7 \mathrm{~mm}$ であった. 
表 1 歯周病䍜患状態

（ポケットの深さ，歯牙の動摇度，歯肉の炎症状態）

\begin{tabular}{|c|c|c|c|}
\hline sub. & pocket depth & mobility & inflammation \\
\hline \multirow{2}{*}{$\mathrm{f}$} & \begin{tabular}{lll|lll}
5634 & 3365
\end{tabular} & \begin{tabular}{llll|llll}
1 & 2 & 0 & 1 & 0 & 0 & 1 & 1
\end{tabular} & \begin{tabular}{llll|llll}
2 & 2 & 2 & 2 & 1 & 1 & 1 & 2
\end{tabular} \\
\hline & \begin{tabular}{llll|llll}
6 & 4 & 3 & 3 & 6 & 3 & 4 & 5
\end{tabular} & \begin{tabular}{llll|lllll}
1 & 0 & 0 & 0 & 1 & 1 & 1 & 2
\end{tabular} & \begin{tabular}{llll|lll|l}
2 & 1 & 1 & 1 & 2 & 2 & 2 & 2
\end{tabular} \\
\hline \multirow{2}{*}{$\mathrm{g}$} & \begin{tabular}{llll|llll}
6 & 6 & 6 & 6 & 6 & 8 & 7 & 6 \\
\end{tabular} & \begin{tabular}{llll|llll}
2 & 2 & 1 & 1 & 1 & 2 & 2 & 1 \\
\end{tabular} & \begin{tabular}{ll|lll}
22222 & 2222 \\
\end{tabular} \\
\hline & \begin{tabular}{ll|l|l|l}
6664 & 5668
\end{tabular} & \begin{tabular}{llll|lllll}
1 & 0 & 0 & 0 & 1 & 1 & 2 & 2
\end{tabular} & \begin{tabular}{llll|llll}
2 & 2 & 1 & 1 & 1 & 122
\end{tabular} \\
\hline \multirow{2}{*}{$\mathrm{h}$} & \begin{tabular}{lll|lll}
432 & 2 & 4565
\end{tabular} & 2220 & \begin{tabular}{llll|llll}
2 & 2 & 1 & 1 & 1 & 2 & 2 & 2
\end{tabular} \\
\hline & \begin{tabular}{llll|llll}
3 & 2 & 2 & 2 & 2 & 2 & 2 & 2
\end{tabular} & $\begin{array}{llll}0 & 0 & 0 & 0\end{array}$ & \begin{tabular}{llll|lllll}
1 & 1 & 1 & 1 & & 1 & 1 & 1 & 1
\end{tabular} \\
\hline \multirow{2}{*}{$\mathrm{i}$} & 432212234 & 2200 & \begin{tabular}{llll|lllll}
2 & 1 & 1 & 1 & 1 & 1 & 1 & 2 \\
\end{tabular} \\
\hline & \begin{tabular}{ll|lll}
4322 & 2 & 2 & 4
\end{tabular} & 01222 & 2111 \\
\hline \multirow{2}{*}{$\mathrm{j}$} & \begin{tabular}{lll|lll}
34 & 432 & 2 & 2 & 32
\end{tabular} & 1000 & 2200 \\
\hline & \begin{tabular}{llll|llll}
6 & 3 & 3 & 2 & 3 & 3 & 3 & 3
\end{tabular} & 1100 & 1100 \\
\hline
\end{tabular}

表 2 成人正常者と歯周病䍜患者の歯冠歯根比

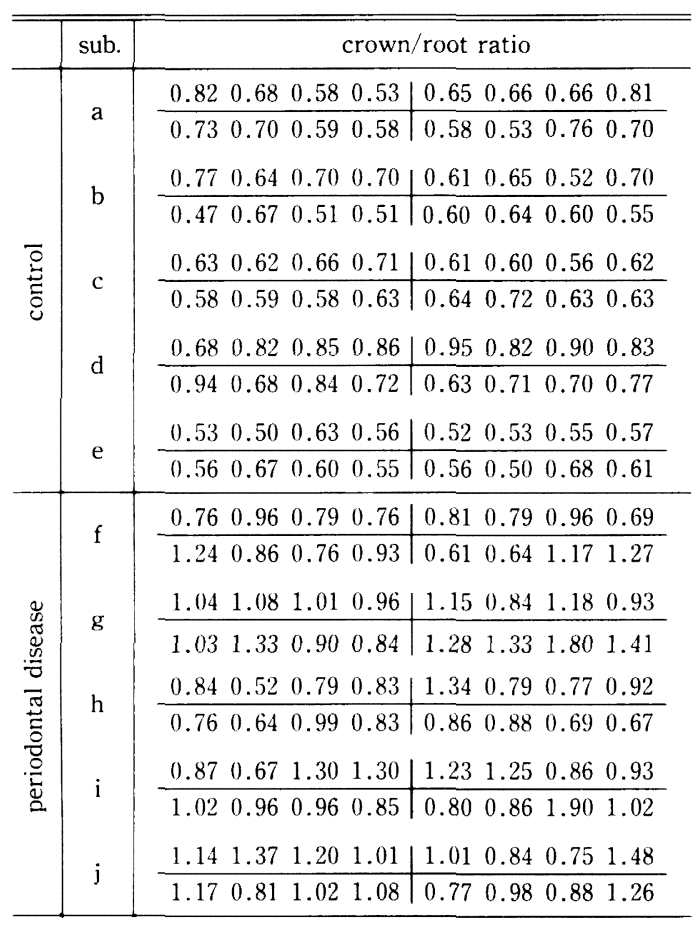

\section{2）歯の動摇度（表 1)}

被験者 $\mathrm{f}$ における動摇度の平均値は 0.8 であり, $\mathrm{g}$ に おいては 1.2 , h においては 0.6 , i においては 1.3 およ び $\mathrm{j}$ においては 1.0 であった. 歯の動摇度は, 被験者 $\mathrm{i}$ が最も不良な臨床所見を呈し, ついで $\mathrm{g}, \mathrm{j}, \mathrm{f}$ および $\mathrm{h}$ の順であった. さらに全臼歯の歯周病罹患者 5 名すべて における動摇度の平均値は $0.8, \mathrm{SD}$ は 0.8 であった。

\section{3）歯肉の炎症状態（表 1)}

歯肉の炎症状態の指数の平均值は被験者 $\mathrm{f}$ においては 1.6 点, $\mathrm{g}$ においては 1.8 点, h においては 1.3 点, i に おいては 1.3 点および $\mathrm{j}$ においては 1.0 点であった. 歯 肉の炎症状態は被験者 $\mathrm{g}$ が最も不良な臨休所見を呈し, ついで $f, h, i$ および j の順であった. さらに全臼歯の歯 周病罹患者 5 名すべてにおける指数の平均值は 1.4 点, SD は 0.6 点であった.

4) 歯槽骨吸収状態（表 2)

上狉第 1 小曰歯の歯冠歯根比の平均值差は, 歯周病罹 患者が成人正常者よりも 0.370 大きく認められた. ま た，上頻第 2 小臼歯でも同様に歯周病䍜患者が 0.292 大 きく，上顎第 1 大臼歯でも 0.267 , 上額第 2 大臼 歯でも 0.264 大きい. さらに下顎第 1 小臼歯でも 0.285 , 下顎 第 2 小臼歯でも 0.308 大きい. また下顎第 1 大臼歯でも 0.436 , 下顎第 2 大臼歯でも歯周病罹患者が 0.431 大き い. このように, いずれの歯にあっても歯周病罹患者の 歯根域が短いことが判明した，また，有意差検定におい ても, すべての場合において $\mathrm{t}$ 值は最小値 2.476 , 最大 值 5.319 を示し, 有意差が認められた.さらに全臼歯部 の成人正常者 5 名すべてにおける歯冠歯根比の平均值は 0.653，SD は 0.107 であった. 一方，歯周病罹患者にお いては, 平均值は $0.985, \mathrm{SD}$ は 0.255 であった.

\section{2. 下顎の側方運動に伴う顆頭の挙動}

研究方法において述べたごとく，成人正常者および歯 周病䍜患者の咬頭嵌合位および，左右両側方人 $1 \mathrm{~mm}$ 間 隔で定量側方運動を行わせた場合の各頡位における側方 運動時非作業側の顆頭の挙動を診査し, small number superposition graph（図 6，7）から，つぎの項目に関 

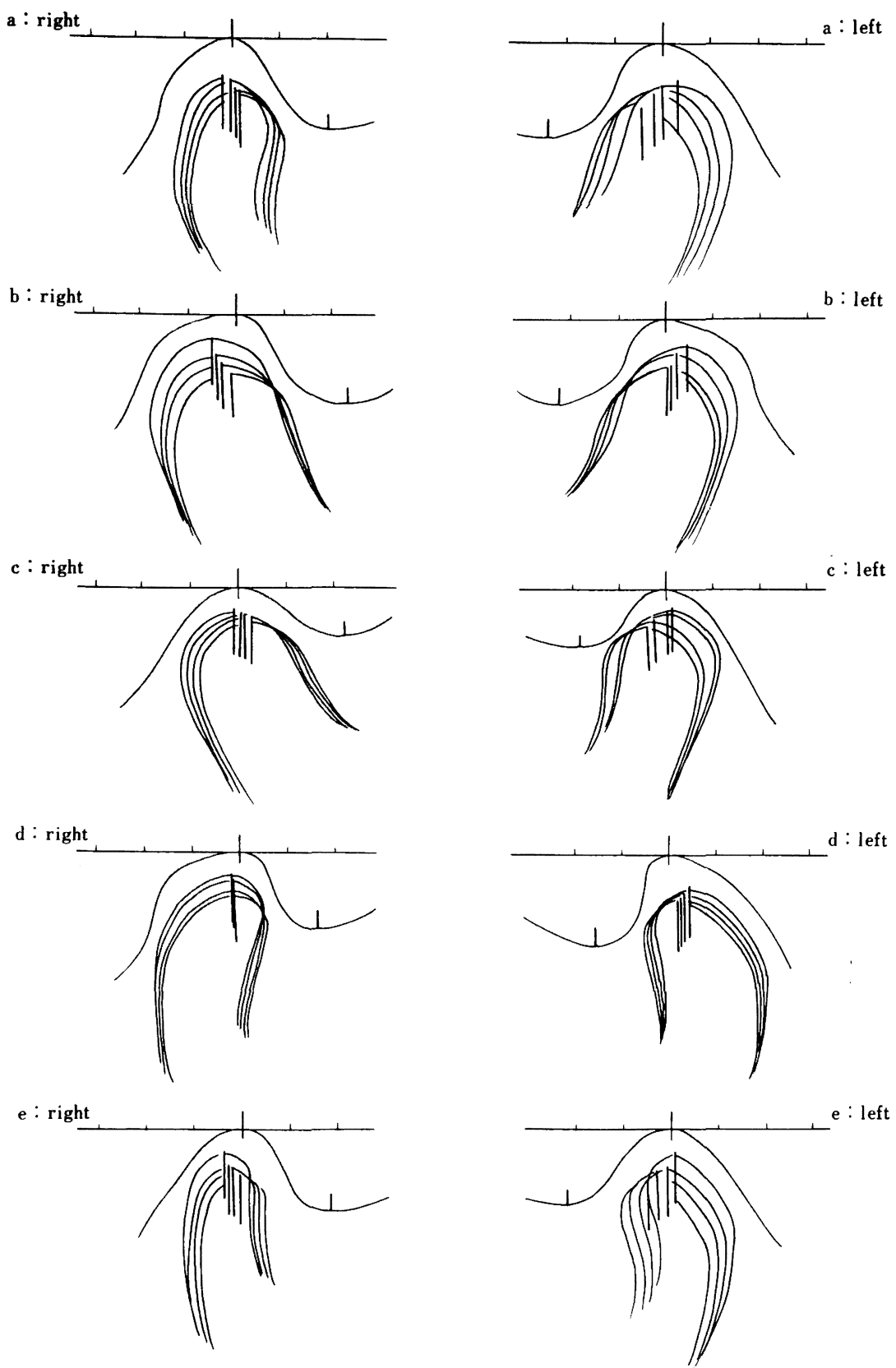

图 6 Superposition graph (成人正常者)

する結果を得た.

1）咬頭嵌合位を基準とした場合における顆頭頂およ び顆頭中心点の移動

成人正常者および药周病䍜患者における左右人の定量 側方運動に伴う顆頭頂および顆頭中心点の移動は, 表 3
に示すとおりである，なかでも顆頭頂において成人正常 者および歯周病䍜患者の間に顕著な差が認められるの は, $2 \mathrm{~mm}$ 移動時の前方移動量で平均值差は $0.555 \mathrm{~mm}$, 顆頭中心点においても同様で, 平均值差は $0.499 \mathrm{~mm}$ で あった。 

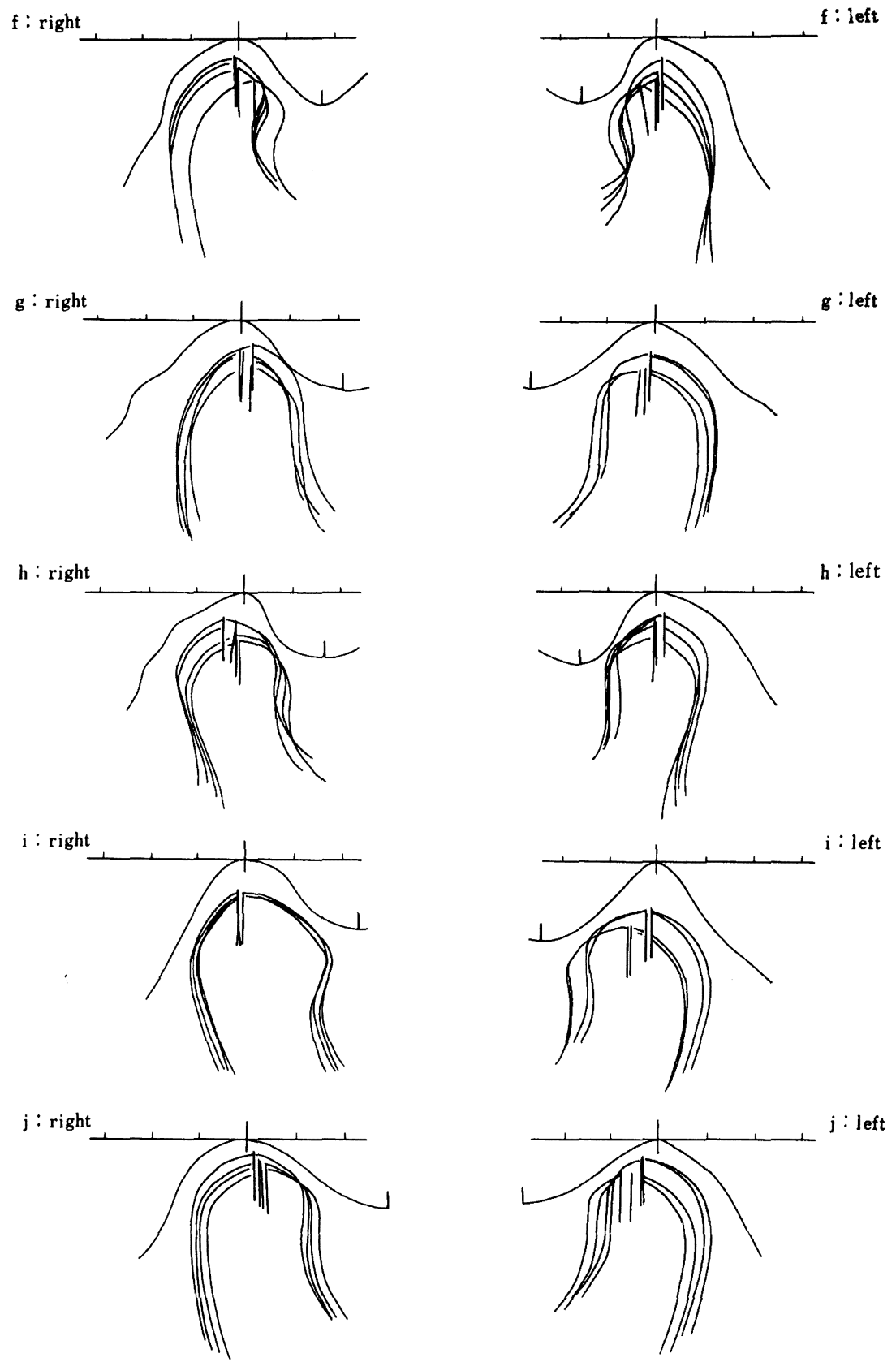

图 7 Superposition graph（歯周病䍜患者）

2）定量側方運動に伴う顆頭の移動の傾斜度 成人正常者および歯周病䍜患者における左右への定量 側方運動に伴う顆頭頂および顆頭中心点の移動の傾斜度 は，表 4 に示すとおりである. なかでも顆頭頂において 成人正常者および歯周病罹患者の間に顕著な差が認めら
れるのは, $1 \mathrm{~mm}$ 側方移動時から $2 \mathrm{~mm}$ 移動時にかけて の傾斜度で平均値差は $19.63^{\circ}$ であり, 顆頭中心点にお いては $2 \mathrm{~mm}$ 側方移動時から $3 \mathrm{~mm}$ 移動時にかけての傾 斜度で $13.47^{\circ}$ であった。 
表 3 成人正常者および齿周病䍜患者における定量側方運動時の顆頭頂と顆頭中心点の移動量

\begin{tabular}{|c|c|c|c|c|c|c|c|c|c|c|c|c|}
\hline \multirow{3}{*}{$\begin{array}{c}\text { 移動方向 } \\
\text { 側方移動量 }\end{array}$} & \multicolumn{6}{|c|}{ 顆頭頂 } & \multicolumn{6}{|c|}{ 顆頭中心点 } \\
\hline & \multicolumn{3}{|c|}{$\mathrm{X}$ : 水平方向 } & \multicolumn{3}{|c|}{ Y : 垂直方向 } & \multicolumn{3}{|c|}{$\mathrm{X}$ : 水平方向 } & \multicolumn{3}{|c|}{ Y : 垂直方向 } \\
\hline & $1 \mathrm{~mm}$ & $2 \mathrm{~mm}$ & $3 \mathrm{~mm}$ & $1 \mathrm{~mm}$ & $2 \mathrm{~mm}$ & $3 \mathrm{~mm}$ & $1 \mathrm{~mm}$ & $2 \mathrm{~mm}$ & $3 \mathrm{~mm}$ & $1 \mathrm{~mm}$ & $2 \mathrm{~mm}$ & $3 \mathrm{~mm}$ \\
\hline \multicolumn{13}{|c|}{ 成人正常者 } \\
\hline mean & 0.718 & 1.371 & 2.051 & 0.911 , & 1.696, & 2.425 & 0.708 & 1.367, & 2.043 & 0.883 & 1.663, & 2.398 \\
\hline SD & 0.403 , & 0.641 , & 0.921 & 0.586 & 0.716 , & 0.818 & 0.389 , & 0.598 & 0.877 & 0.594 & 0.711 & 0.819 \\
\hline \multicolumn{13}{|c|}{ 歯周病罹患者 } \\
\hline mean & 0.560 & 0.816 & 1.562 & 0.427 , & 1.449, & 2.069 & 0.597 , & 0.868 & 1.639 & 0.416 , & 1.456, & 2.043 \\
\hline $\mathrm{SD}$ & 0.477 , & 0.551 , & 0.689 & 0.601 , & 0.640 , & 0.696 & 0.372 , & 0.569 , & 0.578 & 0.616 , & 0.631 , & 0.665 \\
\hline
\end{tabular}

表 4 成人正常者および歯周病䍜患者の定量側方運動に伴う顆頭の移動の傾斜度

「i. p-1」: 咬頭嵌合位から $1 \mathrm{~mm}$ の側方運動

「i. p-2」: 咬頭嵌合位から $2 \mathrm{~mm}$ の側方運動

「i. p-3」: 咬頭嵌合位か $53 \mathrm{~mm}$ の側方運動

「1-2 」: $1 \mathrm{~mm}$ 側方運動時から $2 \mathrm{~mm}$ 側方運動特まで

\begin{tabular}{|c|c|c|c|c|c|c|c|c|c|c|c|c|}
\hline \multirow{2}{*}{$\begin{array}{c}\text { 計測点 } \\
\text { 側方運動 }\end{array}$} & \multicolumn{6}{|c|}{ 顆頭頂 } & \multicolumn{6}{|c|}{ 顆頭中心点 } \\
\hline & i. $p-1$ & i. $\mathrm{p}-2$, & i. $p-3$ & i. $\mathrm{p}^{-1}$. & $1-2$ & $2-3$ & i. $\mathrm{p}^{-1}$, & i. $\mathrm{p}-2$, & i. $p-3$ & i. $\mathrm{p}^{-1}$, & $1-2$ & $2-3$ \\
\hline \multicolumn{13}{|c|}{ 成人正常者 } \\
\hline mean & 47.89 & 49.80 & 50.07 & 47.89 & 49.03, & 48.54 & 48.64 , & 49.55 , & 49.72 , & 48.64 , & 47.84, & 47.58 \\
\hline SD & 21.02 , & 17.00, & 13.16, & 21.02 , & 18.07, & 9.38 & 21.64 , & 16.21 , & 12.28, & 21.64 , & 16.14, & 8.67 \\
\hline \multicolumn{13}{|c|}{ 歯周病䍜患者 } \\
\hline mean & 41.88 & 60.46 , & 51.67, & 41.88 & 68.66 & 36.75 & 38.05 , & 63.18 , & 51.21 , & 38.05 , & 54.04, & 34.11 \\
\hline SD & 33.26 , & 9.65 & 11.37, & 33.26 , & 43.61 , & 28.31 & 29.69 , & 13.21, & 9.29 , & 29.69 , & 76.74 , & 24.27 \\
\hline
\end{tabular}

\section{3）定量側方運動に伴う顆頭の移動距離}

成人正常者および歯周病䍜患者における左右への定量 側方運動に伴う顆頭頂および顆頭中心点の移動距離は, 表 5 に示すとおりである. なかでも顆頭頂において成人 正常者および歯周病䍜患者の間に顕著な差が認められる のは, 咬頭嵌合位から $1 \mathrm{~mm}$ 移動時にかけての移動距離 で, 平均值差は $0.366 \mathrm{~mm}$ である. 顆頭中心点において も同様であり, 平均值差は $0.333 \mathrm{~mm}$ であった.

\section{3、顆頭頂と顆頭中心点との移動傾向の比較}

顆頭頂と顆頭中心点との移動方向について，同一条件 下における定量側方運動に伴う下方移動量と前方移動量 との位置的相関関係について，それぞれの相関係数を求 めた (表 6-1). この結果, 相関係数は, 最大 0.999 , 最小 0.852 , 平均値 0.9670, SD 0.0525 を示した.

\section{4. 成人正常者およひ齿周病罹患者との顆頭移動傾向} の比較

成人正常者および歯周病罹患者との顆頭移動方向につ
表 5 成人正常者および㐘周病䍜患者における定量側方運 動時の顆頭頂と顆頭中心点の移動距離

「i. p-1」: 咬頭嵌合位から $1 \mathrm{~mm}$ の側方運動

「1-2」: $1 \mathrm{~mm}$ 侧方運動時から $2 \mathrm{~mm}$ 侧方運動時まで

「2-3」: $2 \mathrm{~mm}$ 側方運動時から $3 \mathrm{~mm}$ 側方運動時まで

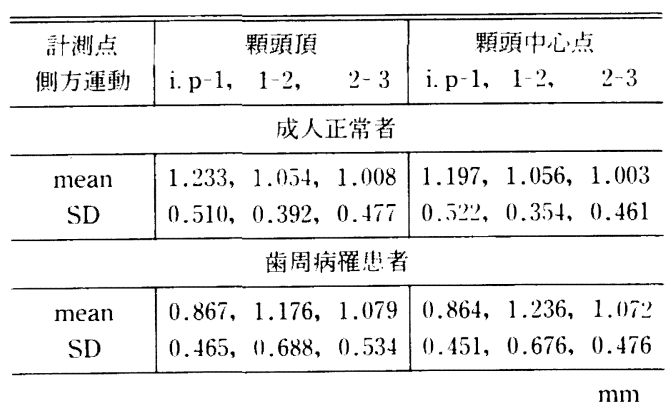

いて，同一条件下における定量側方運動に伴う下方移動 量と前方移動量との位置的相関関係について，それぞれ の相関係数を求めた (表 6-2). この結果, 相関係数は最 大 -0.521 , 最小 0.033 , 平均値 -0.2903 , SD 0.1561 を 示した. また, $1 \mathrm{~mm}$ 側方運動時にあっては, 顆頭中心 
表 6-1 顆頭頂と顆頭中心点の前方および下 方への移動距離についての相関係数

\begin{tabular}{c|cc|cc}
\hline \hline & \multicolumn{2}{|c|}{ 成人正常者 } & \multicolumn{2}{|c|}{ 米周病䍜患者 } \\
\hline 移動方向 & \multicolumn{2}{|c|}{ 前方 } & 下方 & \multicolumn{2}{|c|}{ 前方 } & 下方 \\
\hline $1 \mathrm{~mm}$ & 0.967 & 0.998 & 0.852 & 0.994 \\
$2 \mathrm{~mm}$ & 0.986 & 0.999 & 0.960 & 0.997 \\
$3 \mathrm{~mm}$ & 0.991 & 0.998 & 0.864 & 0.998 \\
\hline
\end{tabular}

表 6-2 顆頭頂と顆頭中心点の定量側方運動に伴う 下方移動量と前方移動量との位㯰的相関係 数

\begin{tabular}{c|rr|r|r}
\hline \hline & \multicolumn{2}{|c|}{ 顆頭頂 } & \multicolumn{2}{c}{ 顆頭中心点 } \\
\hline 移動方向 & \multicolumn{1}{|c|}{ 前方 } & \multicolumn{1}{c|}{ 下方 } & \multicolumn{1}{c}{ 前方 } & 下方 \\
\hline $1 \mathrm{~mm}$ & -0.258 & -0.521 & -0.259 & -0.472 \\
$2 \mathrm{~mm}$ & 0.033 & -0.397 & 0.061 & -0.391 \\
$3 \mathrm{~mm}$ & 0.441 & -0.206 & 0.209 & -0.235 \\
\hline
\end{tabular}

点においての下方移動量, $2 \mathrm{~mm}$ 側方運動時にあっては, 顆頭頂および顆頭中心点においての前方移 動 量, $3 \mathrm{~mm}$ 側方運動時にあっては, 顆頭頂においての前方移動量に 危険率 5\%で有意差を認めた。

\section{IV. 考察}

\section{1. 顆頭運動の矢状面分析の選択理由について}

一般に日常の歯科臨床にあっては, 顆路の計測が恒常 的に行われているが, 操作が繁雑で多量の咬合挙上を不 可避的に強いる pantograph 法22)に比べて，いわゆる 「チェックバイト法」が方法の簡易さから汎用されてお り, 中等度の調節性を持つ咬合器を用いて矢状顆路傾斜 度および水平側方顆路角を計測している。 また，咬合器 によって矢状顆路傾斜度のみの測定を行い, 水平側方顆 路角は計算式により算出する場合や, 矢状顆路傾斜度の みが設定され, 水平側方顆路角は固定的な機構のものが 多用されている状況にある.このようななかにあって， 咬合器の調節機構からも水平側方顆路角に比べ矢状顆路 傾斜度を優先する考え方 ${ }^{23}$ 25) に立脚すると同時に, 運動 量的な面からも矢状面内における検討を最も重要視すべ きであると考える.

また，下顎運動は左右両側同時性を有するものであ り，側方運動時非作業側の動きは, 顆頭の前下方人の移 動とともに作業側顆頭部付近に移動寸る回転中心をもつ 水平面的回転運動を伴う。このような運動様式は, 矢状 面にあって，顆頭がいずれの場合も前下方移動を示すと 同時に, 顆頭の垂直軸が前後的傾斜を大きく示さない傾
34 巻 2 号 (1990)

向 ${ }^{26)}$ を有している. 以上のような基礎的検討 ${ }^{18,21,22,26 ~ 36)}$ をふまえて，本研究にあっては矢状面内における非作業 側顆頭の動きに焦点をしぼったものである.

\section{2. 顆頭頂と顆頭中心点の移動について}

顆頭頂と顆頭中心点の移動に関する検討にあっては, 両者間の同一条件にある前後的および上下的移動距離に 関する相関関係を検討する必要がある.すなわち，研究 結果の表 6-1 について，前方および下方への移動距離に ついての相関係数に関する評価である.

この結果,成人正常者および歯周病罹患者ともに,いず れの条件下にあっても 0.852 以上の值を示した. 特に下 方への移動距離にあってはすべて 0.944 以上の相関係数 を示している，したがって，成人正常者および歯周病罹 患者のいずれも顆頭頂と顆頭中心点との移動距離に関し ては，非常に高度な類似性が存在することを意味してい る. また，前方および下方ともに高度な相関が存在する ことは,移動の方向性も当然類似することであり,この結 果は下顎の側方運動に伴う顆頭部の移動状態が bodily shift であることを意味している.

\section{3. 成人正常者および歯周病罹患者との顆頭移動傾向 の相違について}

從来から，下顎運動に関しては，咬合面を前方要素, 顎関節を後方要素として重要視してきた．特に顎関節は 不可変の要素として, 研究のみならず日常臨床にあって もすこぶる重要な要素として注目をあびてきた。すなわ ち，1700年代からの解剖学的研究にはじまり，顔弓や pantograph を用いた Gysi や中沢 ${ }^{1,2)} の$ 研究, アーム型 コンデンサー法による大石7) の研究，フォトゲージによ る三谷ら ${ }^{8)}$ の研究, マルチフラッシュ撮影による佐久

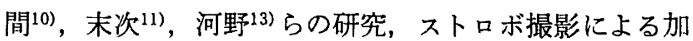
藤 ${ }^{12)}$ らの研究, いわゆる「チェックバイト法」による野 村14) らの研究, Panadent 法を用いた斉藤 ${ }^{15)}$ の研究, 顔面 の外側に取り付けたエアータービンでプラスチックを削 り込み計測した Lundeen ら ${ }^{16)}$ の研究, 磁気スケール出 力のデジタル処理による鈴木 ${ }^{17)}$ の研究など枚挙にいとま がないが，いずれの方法も間接投影的方法にとどまる.

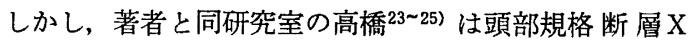
線写真 sectogram の computer 処理による方法によっ て顆頭運動を調查し，また，早坂 ${ }^{37,38)}$ も同様に顎関節の 矢状断面構造について, 形態的調查と同時に関節窩内に おける顆頭の位直について検索を行っている.

そこで著者は, 顆頭の挙動を直接的に調査でき, かつ, 


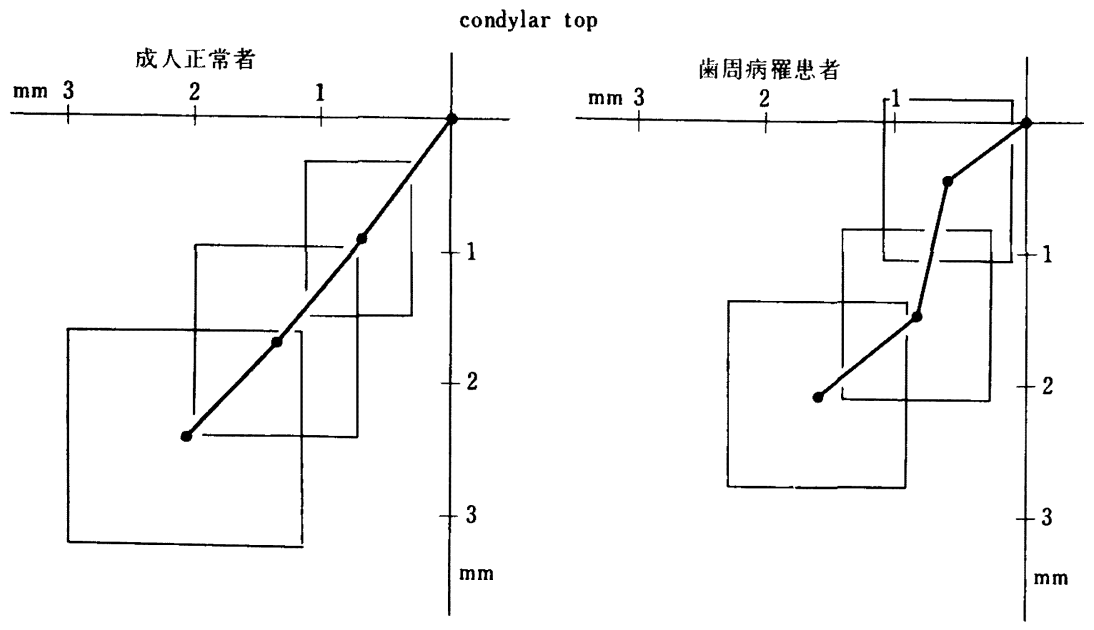

図 8 顆頭頂における顆頭運䡃

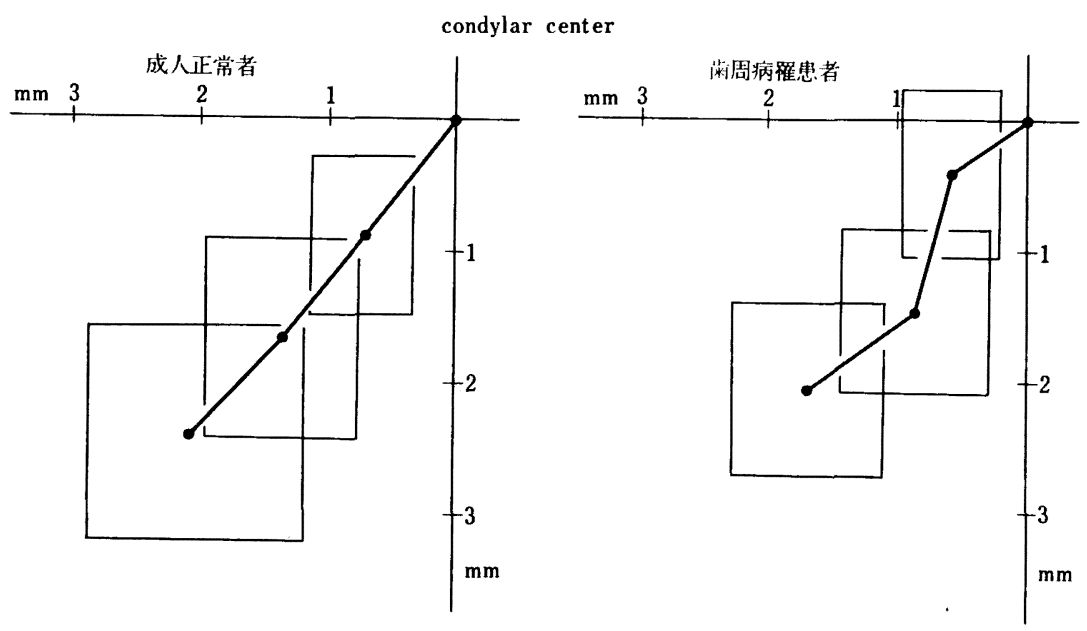

図 9 顆頭中心点における顆頭運動

その詳細にわたっての分析が可能な本研究方法を選択し た. 研究結果の表 6-2 にみられるごとく, 成人正常者と 歯周病䍜患者との間には, 顆頭頂および顆頭中心点のい ずれにあっても，前方移動量，下方移動量ともに相関倸 数がいちじるしく小さい值を示した. 特に前方移動量に おける $2 \mathrm{~mm}$ の側方運動時にあっては, 相関係数が 0.061 以下を示しており，危険率 5\% で有意差を認め, 両者の顆頭の挙動は明らかに異なることを意味してい る. したがって, 両者の比較検討は研究上すこぶる有意 なことと考える. そこで，両者の比較検討を行うにあた っては, 顆頭頂または顆頭中心点の両者について, 前方 移動量および下方移動量からそれぞれの基準点の移動方 向をグラフ化し, 図 8，9 に示した. 図 8，9 にみられる
ように，成人正常者では，顆頭頂および顆頭中心点のい ずれにあっても下顎の側方運動に伴う移動は直線的であ り，一方，歯周病䍜患者のそれは明瞭なジグザグ型を示 している.さらにこの傾向を詳細に検討すると， $1 \mathrm{~mm}$ 側方運動時にあっては，歯周病䍜患者の基準点の移動方 向, 補緅学分野でいら顆路角は, 顆頭頂では 37.3 度, 顆頭中心点では 34.9 度であり, 成人正常者よりもそれ ぞれ 14.5 度, 16.0 度小さな值を示している.また， $1 \mathrm{~mm}$ 側方運動時から $2 \mathrm{~mm}$ 側方運動時にかけては 75.9 度拉よび 73.9 度であり, 成人正常者よりもそれぞ れ 25.7 度，20.0 度大きな值を示しており，危険率 $5 \%$ で有意差を認めた. 一方, $2 \mathrm{~mm}$ 側方運動時から $3 \mathrm{~mm}$ 側方運動時にかけては 39.7 度および 37.3 度であり, 成 
$138-382$

補緅誌

人正常者よりもそれぞれ 7.3 度, 10.1 度小さな值を示し ている.

このように, 成人正常者および歯周病罹患者における 下䫟の側方運動に伴う顆頭の移動傾向は, 顆頭頂, 顆頭 中心点ともにほとんど同じような相違を示している.す なわち，歯周病罹患者にあっては，咬頭嵌合位から 1 $\mathrm{mm}$ 側方運動にいたる過程において, 矢状顆路傾斜角は 小さくなり，前方，下方移動量ともに少なくなる．移動 直線量も成人正常者の場合よりも顆頭頂で $60.7 \%$, 顆頭 中心点で $64.3 \%$ に短縮している. また, $1 \mathrm{~mm}$ 側方運動 時から $2 \mathrm{~mm}$ 側方運動時にかけては, 矢状顆路傾斜角 は 20 度以上も大きくなり, 70 度以上の急激な下降を示 している. したがって前方移動量は成人正常者の場合よ りも顆頭頂で $39.2 \%$, 顆頭中心点で $38.2 \%$ に減少を示 すが，下方移動量は顆頭頂で $130.2 \%$ ，顆頭中心点で $133.3 \%$ であり, 両者の差は小さい. さらにまた $2 \mathrm{~mm}$ 側方運動時から $3 \mathrm{~mm}$ 側方運動時にかけては, 急激な下 降は消退しなだらかな傾斜を示すようになる。このよう な歯周病䍜患者の顆路は, 全体的には直線的な成人正常 者の移動線の上方部分をぬうような $\mathrm{S}$ 状カーブを呈す る.したがって, 咬頭嵌合位から最大 $3 \mathrm{~mm}$ の側方運動 時にかけては, 全体の前下方移動量の直線距離は顆頭頂 で $81.6 \%$ ，顆頭中心点で $83.9 \%$ に減少している.これ らの結果, 歯周病䍜患者における下預の側方運動に伴う 非作業側の顆頭の挙動は, 成人正常者のそれとは明らか に異なる様相を呈している.

このような現象についての原因を推察すると，まず第 一には，関節窩内における変化についてである．結果に 示されているように, 移動初期における傾斜角の減少は, 顆頭の前方移動の許容性が増加したことを示し, 咬頭嵌 合位付近における顆路規制条件の緩和を意味しているも のと考えられる. ついで，中期における急激な下降は， 関節窩前壁の影響を受け，移動初期における下方移動量 の補償を行うような挙動であり，これにより全体的な顆 頭の移動位置を修正しているものと思われる. さらに運 動末期においては, 成人正常者の移動方向と近似の傾斜 角を示すようになる.これは，関節窩前壁の下方部分の 形態にはほとんど変化がないことを意味している. しか し前述のように，顆頭の全体的な前下方への移動量は減 少して, $3 \mathrm{~mm}$ 側方運動時にあっては成人正常者の場合 と異なり，いずれの基準点も上後方で終末しており両者 の直線距離差は顆頭頂では $0.61 \mathrm{~mm}$, 顆頭中心点では $0.54 \mathrm{~mm}$ を示している. しかし，いうまでもなく，長 期間にわたって咬合条件の変化が顎関節の形態に変化を
34 巻 2 号 (1990)

与えていることは否定することはできない，したがっ て，咬耗に伴う関節窩および顆頭の形態に関する調査が 行われる必要があるものと考える，すなわち，下顎運動 における前方要素としての咬合面の条件が, 後方要素と しての䪽関節，特に関節窩および顆頭の形態とその運動 様式に影響を与えるものであることが示唆された。

さて，もう一方の原因としてあげなければならないの は, 咬合面形態の経時的な形態変化が下顎の滑走運動路 自体に不可避的影響を及ぼし，ひいては顆頭の挙動に も大きな変化が生じることである，いうまでもなく，前 方要素としての上下頡の咬合面間には, 咀嚼に伴って常 時荷重が加えられている.これにより咬耗が生じ, 経常 的に下顎運動路が影響を受け，さらにこれらが長期にわ たった場合には, 当然, 下鿓運動様式も前方要素の変化 と同調する変動を示すことが考えられるので, 今後さら に診査する必要があるであろう.

本研究では，側方運動量についてはレジンコアーを用 いて咬合位がずれないよう監視しながら撮影を行った が，側方運動の指示にあっては，指導や規制などは行わ ずに，被験者が通常自然にとりうる側方運動としたの で，咬耗を有する歯周病罹患者特有の運動傾向を示した ものと考える. すなわち, 側方滑走が容易になり，この 影響によって下顎骨全体の移動は作業側の顆頭を中心と する回転的運動から，全体が側方に移動するような side shift 的な挙動が大きくなり，この結果，非作業側の顆 頭運動に影響をおよぼし，前下方への移動量の減少につ ながったものと考えられる.

また，被験者 d, f，i の右側顆頭にみられるように， 成人正常者および歯周病䍜患者の両方において，前下方 移動量のきわめて少ない挙動を示す例もみられた.これ は，下狉運動の非定量性，さらに䫟関節内構造の複雑性 の影響が示唆されたものと思われ，今後さらにこの点に おける検索が必要であろう。

しかしながら，このような側方運動に伴う顆路が咬合 面の条件によって大きな相違を示すことは, 当然, 臨床 的にも影響を及ぼすことになる．すなわち，咬合面の 位置変化を捕えて後方要素, 特に矢状顆路角を計測す る,いわゆる「チェックバイト法」にあっては, 側方咬 合位から顆路角を計測する場合に歯周病䍜患者におい て，側方運動量の多寡が見かけの顆路角を大きく左右す ることが考えられる. したがって，歯周病䍜患者の顆路 計測の臨床技法の選択において配慮する必要性が示唆さ れたものと考える. 


\section{V. 結 論}

著者は，歯科補緅学分野にあって特に重要視される 下䫑の側方運動に伴う関節窩内における顆頭の挙動に関 して, 頭部規格断層X線撮影装置 Sectograph による規 格断層X線写真の computer による複数画像重好合せ 技法 superposition methodによって, small number superposition graph を作成し，これに基つきき,上下顥全 歯を有する成人正常者および歯周病䍜患者について，前 歯部において左右それぞれ 1,2 および $3 \mathrm{~mm}$ の定量側 方運動に伴う非作業側の顆頭の挙動に関する 診查を行 い,つぎのような結果を得た。

1. 咬頭嵌合位を基準として, 顆頭頂および顆頭中心 点の移動に関する診查の結果, 成人正常者における左右 への定量側方運動に伴う顆頭頂および顆頭中心点の移動 は，明瞭な直線型を示した。一方，歯周病䍜患者におけ る左右への定量側方運動に伴う顆頭頂および顆頭中心点 の移動は、明瞭なジグザグ型を示した. なお，両者とも に, 顆頭頂および顆頭中心点の移動状況は著しく類似し ている.

2. 歯周病䍜患者は咬耗が生じているにもかかわら ず，顆頭頂と顆頭中心点との移動傾向において成人正常 者と非常に近似している結果を示した．したがって，下 䫑の側方運動に伴う顆頭の移動様式は bodily shift であ ることが証明された。

3. 成人正常者および歯周病䍜患者との顆頭の前下方 移動量は，いずれの側方運動量にあっても相違を示し， 特に最大側方移動量 $3 \mathrm{~mm}$ の場合にあっては, 後者は前 者の約 $80 \%$ であった.

4. 本研究において選択した成人正常者と, 歯周病䍜 患者との間に咬合条件の相違が疑われた。

稿を終わるにあたり，こ蒩篤なご校閲を睗った，明海大学菊科 補級学第 1 講座柳生嘉博教授に深甚なる竦意を表します。また， 種々ご助言を賜った、明海大学菊周病学諈座池田克已教授ならび に明海大学口腔解剖学第 1 諢座久米川正好教授に深謝いたしま †.

なお，本論文の要旨は，第 47 回明海大学大学院研究 発 表会 (平成 1 年 4 月 22 日, 坂戸市) において発表した.

\section{文献}

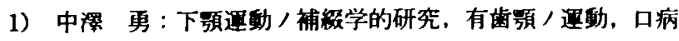
誌, $13: 1 \sim 98,1939$.

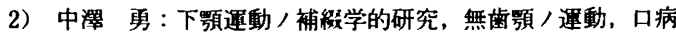
誌, $14: 160 \sim 165,1940$.

3) Posselt, U. : Movement areas of the mandible, J Prosthet Dent, $7: 375 \sim 385,1957$.

4）粗美 弘：咬合高径の変化によって現われる口内法描記上 の各運動路の変化について, 補緅誌, $5: 52 \sim 57,1961$.

5）根本一男：有歯额の下顎切歯点における 3 次元的運動限界 の研究, 補緅誌, $6: 1 \sim 40,1962$.

6) 藍 稳: 切歯点部における咀啋運動の解析, 補緅誌, $6: 164 \sim 200,1962$.

7）大石司郎：アーム型運動分解器とコンデンサー法による下 䫑運動の研究，第 1 報 測定装置について, 口病誌, 29 ： 164 180, 1962.

8）三谷春保,山下 效, 川畑 衛ほか：電気的下頡運動記録 の一新法, フォトゲージシステムについて, 歯科医学, $26: 415 \sim 419,1963$.

9）石原寿郎，蓝 稔：咬合に関する見解の種々相 2 下顎 運動について, 歯界展望, $31: 29 \sim 40,1968$.

10）佐久間孔毅：マルチフラッシュ装直による有歯滪の前後お よび開閉運動の研究, 口病誌, $26: 1511 \sim 1536,1959$.

11）末次恒夫：マルチフラッシュ装固による無菌額の前後, 開 閉運動並びに下滪位の研究, 補釉誌, 5:131 169, 1961.

12）加藤吉昭：ストロボ撮影法による下䫑運動, 殊に補緅学的 見地からみた運動に関する研究, 日大医誌, 19:1451〜 1487, 1960.

13）河野正司：下顎の矢状面内運動に対応する顆頭 運動の研 究, 第二報 マルチフラッシュ装㯰による夭状面運動軸の 解析, 補緅誌, $12: 350 \sim 380,1968$.

14）野村孝太郎：側方咬合における咬合器の再現性と運動様式 に関する研究, 補緅誌, $15: 239 \sim 266,1971$.

15）斉藤文明：下矤頭の運動路に関する研究，歯科学報，79： $721 \sim 761,1979$.

16) Lundeen, H.C. and Wirth, C.G. : Condylar movement patterns engraved in plastic blocks, J Prosthet Dent, $30: 866 \sim 875,1973$.

17）鈴木 温：ディジタル方式下㯋運動測定器による下影限界 運動の 6 自由度解析, 補緅誌, $31: 712 \sim 725,1987$.

18）清野晃孝, 近江谷尚紀, 田島篤治ほか：咬合と滪関節に関 する研究 $\mathrm{V}$ 咬合举上装置装着による顆頭位の変化につい て, 補緅誌, $29: 1416 \sim 1425,1985$.

19）木村吉太郎, 楠 正夫, 松村雄治ほか：PERIO WORKSHOP 歯周病の基礎・臨床・予防, 210 223, ライオン歯 科衛生研究所, 東京, 1976 .

20）島田義弘：予防歯科学, 27 75, 医歯薬出版, 東京, 1983 .

21）早坂正博, 高橋健二, 田島篤治ほか：Sectographによる 顆頭位の研究、第 1 報 各下䫛位に求ける顆頭位につい て, 補緅誌, $27: 550 \sim 572,1983$.

22）高梠健二, 近江谷尚紀，田島篤治ほか：Sectographによ 
る顆頭位の研究, 第 5 報 hinge bow および pantograph のクラッチトレー装着による顆頭の挙動について, 補緅誌, $29: 139 \sim 157,1983$.

23）高橋健二：下顎の前方および侧方運的時における顆頭の動 きについて ( 1 報), 補緅誌, $31: 631 \sim 645,1987$.

24）高橋健二：下頢の前方および側方運動時における顆頭の動 きについて ( 2 報), 補緅誌, $31: 791 \sim 804,1987$.

25）高橋健二：下蕷の前方および側方運動時における顆頭の動 きについて ( 3 報), 補緅誌, $31: 1077 \sim 1090,1987$.

26）和栗範幸, 清野晃孝, 渡辺義宏ほか: 咬合と顎関節に関寸 る研究VII 下買側方運動に伴なう非作業側の移動路傾斜 度について, 補緅誌, $32: 1122 \sim 1131,1988$.

27）早坂正博, 近江谷尚紀, 田島篤治ほか：Sectograph によ る顆頭位の研究，第 2 報 咬合力発現時における顆頭の移 動について, 補緅誌, $27: 573 \sim 584,1983$.

28）高橋健二, 近江谷尚紀, 田島篤治ほか：Sectograph によ る顆頭位の研究, 第 3 報 成人および小児における T.M.J. 付近の状態と顆頭の動きについて, 補綴誌, $27: 802 \sim 818$, 1983.

29）早坂正博, 近江谷尚紀, 田島篤治ほか：Sectograph によ る顆頭位の研究，第 4 報 開口初期における顆頭位につい て, 補緅誌, $27: 1167 \sim 1181,1983$.

30）早坂正博, 近江谷尚紀, 田島篤治ほか：颚関節症患者の顆 頭位に関する研究 (I) 正常咬合者と顎関節症患者患側に おける顆頭位について, みちのく歯学誌, $14: 48 \sim 50$,
1983.

31）早坂正博, 近江谷尚紀, 田葛篤治ほか: 顎関節症患者の顆 頭位に関する研究（II）䫘関節症患者の患側と非患側にお ける顆頭位について, みちのく畨学誌, $14: 50 \sim 52,1983$.

32）高橋健二, 近江谷尚紀, 田島篤治ほか：咬合再構成に执け る治験（I）多量の咬合挙上をともなう症例, 東北歯大誌, $11: 20 \sim 36,1984$.

33）酒井靖彦, 近江谷尚紀, 田易篤治ほか：咬合と眔関節に関 する研究 I 咬合再檏成前後における顆頭位について, 補 緅誌, $29: 1070 \sim 1094,1985$.

34）清野晃孝, 近江谷尚紀, 田島篤治ほか：咬合と影関節に関 する研究 II 残存歯 Splint を行った部分欠損例の咬合再 構成前後における顆頭位について, 補緅誌, $29: 1250$ 1262, 1985.

35）高橋健二, 近江谷尚紀, 田島篐治ほか：咬合と顎関節に関 する研究 III 顆頭位の強制的移動の可能性について, 補経 誌, $29: 1310 \sim 1324,1985$.

36）早坂正博, 近江谷尚紀, 田島篤治ほか：咬合と頡関節に関 する研究IV 影関節症候群を有する患者の咬合再盽成につ いて, 補緅誌, $29: 1361 \sim 1373,1985$.

37）早坂正博 : 頭部規格断層 X 線摄影による顎関節の矢状断面 形態に関する研究 ( 1 報), 補緅誌, $32: 839 \sim 852,1988$.

38）早坂正博 : 頭部規格断尿 X 線撮影による頷関節の矢状断面 形悲に関する研究 ( 2 報), 補緅誌, $32: 993 \sim 1001,1988$. 